\title{
The Impact of Life Philosophy and Major Field of Study on Brazilian Students' Knowledge of Biological Evolution
}

\author{
Guilherme Ramos Demetrio $^{1}$ (D) - Uedson Pereira Jacobina ${ }^{1}$ (D) $\cdot$ Kim Ribeiro Barão $^{1}$ (D)
}

Accepted: 21 September 2021 / Published online: 16 October 2021

(c) The Author(s), under exclusive licence to Springer Nature B.V. 2021

\begin{abstract}
Evolutionary theory (ET) is the unifying theory of Life Sciences, but it is largely misunderstood and the target of dispute in many countries, mainly because of conflicts with religious beliefs. Brazil is a country with a culture that is deeply rooted belief in God. In this paper, we report a study in Brazil where we applied a 12-question questionnaire to understand the relationship among the major field of study and the self-declared religious and philosophical context on the knowledge of evolutionary theory by Brazilian freshmen. We answer the following questions: (1) Is there a difference in ET comprehension according to the major field of study? (2) Are religious and philosophical contexts related to the comprehension of ET? (3) Are major field of study and religious/ philosophical contexts together related to the comprehension of ET by Brazilian freshmen? A total of 153 freshmen students answered our questionnaire. Students from the Biological Sciences fared better than students from most other major field of study but were equal to students of Humanities. The philosophical perception of life had a major correlation with their knowledge about evolution, with self-declared atheists and agnostics showing better performance than religious students. There were no clear trends in the interaction of major field of study and philosophy of life. We discuss these results in the light of the rising ideological activism in Brazilian society since philosophy of life was the main driver of evolutionary theory perception. We highlight the importance of scientists and teachers in reassuring the role of science and scientific knowledge in modern societies.
\end{abstract}

Keywords Creationism $\cdot$ Evolutionary biology $\cdot$ Misconceptions $\cdot$ Religion $\cdot$ Teaching evolution

Kim Ribeiro Barão

kim.barao@penedo.ufal.br

1 Unidade Educacional Penedo, Universidade Federal de Alagoas, Penedo, AL, Brazil 


\section{Introduction}

Evolutionary theory (ET) is the unifying theory of the Life Sciences, traversing all areas within it and inspiring several hypotheses and scientific research (Brewer \& Smith, 2011; Meyer \& El-Hani, 2005). More than sixty nations consider biological evolution as the unique and most acceptable explanation to the understanding of life mechanisms on Earth (Interacademy Panel 2006). Although the cornerstone for the Life Sciences, ET is still misunderstood by students and the general public (Johnson \& Lark, 2018), and its principles and foundations are the target of dispute, mainly because of conflicts with religious beliefs (Abrantes \& Almeida, 2006; Oleques et al., 2011). Indeed, the creationist speech is suggested as the main reason for the biased teaching-learning process and comprehension of ET (Baker, 2010, 2013; Berkman \& Plutzer, 2010).

Creationism and ET do not deal with the exact same questions, as creationism proposes an explanation to the origin of life, whereas the ET explains the changes in organisms through time, and both are epistemologically organized in different ways (Sepúlveda and Hani 2004). A main conflict between these two worldviews is directly related to the teleological aspect of creationism (Egger et al., 2018), where there is a "final purpose" underlying the natural processes, a fit mechanism for the belief that a higher power has created all living beings. For example, 4 in 10 Americans agree with the statement that God created humans "in their present form" at some point in the last 10,000 years. This view was strongly influenced by the respondent religion, and Christian respondents varied 34 and $56 \%$ in agreement with the statement, while among those respondents that declared not being part of a specific religion only $14 \%$ agreed with the statement (Brenan, 2019). This is similar in Brazil, where a public inquiry showed that on average $25 \%$ of the respondents agreed with the same statement, with an increase to $60 \%$ of agreement among Catholics and evangelical respondents (Datafolha, 2010). This kind of thinking may actively influence students perception about ET (Kellemen 2012).

The cultural roots of each country must be considered to delineate the peculiarities of the teaching of biological evolution (Oliveira \& Cook, 2018). Recently, the advocacy of creationism over ET has risen worldwide, bringing up concerns about the consequences of ET replacement by creationism during science classes (Miller et al., 2006; Harmon, 2011; Blancke et al., 2016). Radical supporters of creationism believe teaching ET undermines children and adult's religious beliefs, advocating equal status for creationism and evolutionary theory in science classes as the best alternative to understand the origin of species and life diversity and to allow students to make their own choices. These discussions affect academic freedom by overwhelming the classroom environment and oppressing research in biological evolution.

The deep-rooted adherence to a belief in God (Caldeira et al., 2012; Penteado et al., 2012; Silva \& Prado, 2010) makes the Brazilian reality close to global trends. Part of the Brazilian population (54\%) accepts ET as a valid scientific theory, but the majority (89\%) believe creationism should be taught in schools, with $75 \%$ of this latter group suggesting that creationism should replace ET in schools (Brum et al., 2005). Brazil is a secular nation (Brasil, 1988) but holds the largest Catholic population in the World (Alves et al., 2017), and most of its holidays are religious. Recently, Evangelicals are increasing to the detriment of Catholics (Follmann, 2017), which is linked to the outcry of teaching creationism in schools rather than the teaching of biological evolution. For example, in the Rio de Janeiro State, an evangelical governor allowed the teaching of 
creationism in science classes as an alternative to evolution (Martins 2004), enabling teachers to ignore the Brazilian directives for science teaching.

At the national level, several ministers have demonstrated their understanding that "Darwin's theory is doctrinal, and as such, should be taught like religious practices" (Navarro, 2018), joining forces with the outcry for teaching creationism in basic and higher education (Escobar, 2019; Oliveira \& Cook, 2018; Silva \& Prado, 2010). However, the National Common Curricular Basis, ruled by the Ministry of Education (MEC), recognizes ET as the integrative pillar and main component of science education in Brazil (Brasil, 2006, 2017).

Students of Brazilian elementary and high schools feel conflicted to contrast their religious worldview and the explanatory models of science, especially when studying ET (Sepúlveda and El-Hani 2004; Amorin and Leyser 2009), which is further aggravated by ambiguous messages in textbooks widely used in schools (Oliveira \& Cook, 2018). On the other hand, teachers of ET face difficulties, such as fragmented knowledge in the teaching material and curriculum, ultimately leading to students' poor knowledge about ET (Zanberlan and Silva 2012). Also, teachers' knowledge of ET is sometimes misled, and they fail to clearly distinguish properties of science from religion and their view of nature (Tidon \& Lewontin, 2004).

In 2010, Penteado and colleagues used a ten-question questionnaire to investigate the knowledge about ET by freshmen of a Brazilian university (Pazza et al., 2010). Considering their intended major field of study, the students' perception about ET showed a higher propensity of Biological Science students to accept ET than students of other major field of study (Pazza et al., 2010). The authors also highlighted the necessity to consider the religious or philosophical worldview to better understand the teaching and learning context, but they did not include this variable in their analyses.

Through a 12-question questionnaire, we tried to understand the relationship of the major field of study and the self-declared religious and philosophic context on the knowledge of ET by Brazilian freshmen enrolled in higher education in Brazil. To evaluate their main mistakes and successes about ET, we answer the following questions: (1) Is there a difference in ET comprehension according to the major field of study? (2) Are religious and philosophical contexts related to the comprehension of ET? (3) Are major field of study and religious/philosophical contexts together related to the comprehension of ET by Brazilian freshmen?

\section{Material and Methods}

\subsection{Data Collection and Processing}

Our study was based on the questionnaire about biological evolution by Pazza et al. (2010), after minor changes: we excluded two of their questions about human evolution, and included four questions about the age and evolution of the Earth, the importance of the fossil record for understanding biological evolution, and creationism. Thus, our final questionnaire comprised 12 questions (Table 1). Questions about human evolution were excluded because we understand that human evolution is a topic within biological evolution, being regulated by the same processes.

The questionnaire also included a block of questions about the major field of study, the course start date, and the period the interviewee was taking at the time of the answer, as well as their self-declared religious or philosophical beliefs (available 
Table 1 Questionnaire about Earth and biological Evolution. The expected answers are highlighted in bold

Ques- Question statement and answer alternatives

tion

number

1 Which of the estimates below is closest to the age of Earth?
A. 6500 years
B. 10 million years
C. 4.5 billion years
D. 6.5 billion years
E. 15 billion years
F. I do not know

$2 \quad$ How did species diversify?

A. Species descend from other species, which are modified from different selective pressures

B. All species descend from other species, which are modified based on different intensities of use or disuse of certain characteristics

C. The species did not diversify, all were created as they are in a single event or at different events over time

D. Species were created at once and later diversified

E. I do not know

3 What is the importance of the fossil record for understanding the organization of life on Earth?

A. The fossil record is not important, because all life forms were created in a short time span and their current shape and form

B. The fossil record shows the gradual change of the taxonomic groups we currently see on Earth

C. The fossil record can aid to infer the phylogenetic relationships, facilitating the understanding of biological evolution and the diversification of life on Earth

D. I do not know

4 What was the novelty of Darwin's idea regarding the modification in living organisms compared with the existing theories at that time?

A. The struggle for survival, where the fittest will survive and thus present a differential reproductive success, while the less apt individuals can be led to extinction

B. The process of accumulation of mutations that causes extinction

C. The law of use and disuse

D. The origin of life from an inanimate matter

E. The transformation of the organisms by internal transforming power

5 The random effect plays a key role in the evolution of species. In what way?

A. By selecting the more suitable organisms

B. By acting both as a source of variation (mutations) and as a fixation of neutral features (genetic drift)

C. By acting as an internal power that leads the organisms to evolution

D. By being the natural selection itself

E. By altering the shape of the organisms according to their needs

6 When a given variation allows a higher survival and inheritance to new generations, its frequency within the population will increase through a process called:
A. Mutation
B. Natural selection
C. Genetic drift
D. Use and disuse
E. Recombination

7 The variations are referred to as the fuel to evolution. The main sources of variation are:
A. Natural selection and migration
B. Mutation and recombination
C. Internal power and necessity
D. Mutation and natural selection
E. Recombination and natural selection 
Table 1 (continued)

Ques- Question statement and answer alternatives

tion

number

8 Darwin's natural explanations excluded the humans as belonging to a species raised in isolation. It is correct to assure about evolution:

A. The man is the most evolved organism

B. The man descends from the chimpanzee

C. Chimpanzees and men have a common ancestor

D. White people are more evolved than black people

E. The man descends from gorillas

9 A human arm and a batwing are examples of:
A. Analogy
B. Mutation
C. Homology
D. Vicariance
E. Genetic drift

$10 \quad$ How would be Lamarck's explanation for the increase of the giraffe's neck?

A. It has never enlarged; it has always been this way

B. The giraffes with a little longer neck took advantage of the others because they could eat more, thus they left a higher number of offspring

C. The giraffes stretched their necks according to their needs promoting its elongation, which was transmitted to the offspring

11 Is the statement 'Most of the mutations are harmful' correct?
A. Yes
B. No

12 Regarding the causes of the emergence and evolution of life, which of these answers best fits your line of thought?

A. Given the complexity of life, many situations, structures, and natural processes could not be simply governed by chance. There is the existence of superior intelligence that is responsible for the creation of all these situations, that is, there is an intelligent design

B. All species of living beings have evolved, and natural selection, adaptation, and random processes such as genetic drift and neutral selection can be hypothesized as driving forces for the functioning of these events

on Online Resource 1). The interviewees could declare to which religious group they belonged, if they belonged to multiple religious groups, or if they considered themselves agnostic or atheist. From hereafter, we call the religious or philosophical contexts the philosophy of life.

The questionnaire was hosted in the Google Forms platform and answers were taken from December 2018 through May 2019. Only one answer per participant was recorded. The anonymity of participants was guaranteed through the Google Forms platform. The research was advertised on social media and emailed to several Brazilian universities asking their help to publicize it among their students.

By the time we closed the questionnaire, 849 participants had submitted their answers. The full dataset was downloaded from Google Forms as a spreadsheet and the data was scrutinized for inconsistencies or incomplete records, such as attending period zero or not declaring the major field of study, after which 820 completed questionnaires were considered valid. According to the number of undergraduate students enrolled in high education courses in 2018 (Brasil, 2018) our sample size is statistically adequate in terms of sampling sufficiency (Additional information provided on Online Resource 1, Table S2). 
To evaluate the relationship between major field of study and philosophy of life on the comprehension of biological evolution of Brazilian freshmen, the dataset was filtered to select the answers by participants who were enrolled in the first or second periods of their courses, accounting for 153 valid answers. Participants were grouped according to their intended major field of study as stated in Table 2. As we conducted a non-probabilistic sampling, our sample did not present the same distribution of undergraduates enrolled per major field of study when compared to the distribution of the total undergraduate population (additional information provided on Online Resource 1, Table S3). Thus, it is possible that there was a bias of interest in the questionnaire; undergraduates more interested in ET-irrespective of their majoring areas-could be more prone to answer to our questionnaire, since responses were voluntarily gathered from each respondent. However, we understand that this bias would be diluted as we focused on freshmen students, a group of students with the same expected level of knowledge about this subject, considering that the high school system in Brazil includes Evolutionary Theory as one of the primary axes of its mandatory Biological Science courses (Brasil, 2017). This enabled us to disentangle the correlation of undergraduate programs and students' ET knowledge, considering that majors in some areas would naturally drift apart from this kind of subject.

All 153 answers were used for exploratory and descriptive analyses and to assess the correlations with the major field of study. To evaluate the philosophy of life on the understanding of ET, less representative categories were excluded due to the low amount of samples, such as Afro-Brazilian religions $(N=3)$, multiple religious belonging $(N=13)$, and spiritism $(N=7)$, leaving 130 answers for analysis.

\subsection{Statistical Analyses}

All statistical analyses were conducted in R v. 3.6.1 (R Core Team, 2019). Descriptive statistics were calculated using the $d d p l y$ function of the plyr package (v. 1.8.4) (Wickham 2011), and graphics were drawn with the package ggplot (v. 3.2.1) (Wickham 2016). The relationship of major field of study and philosophy of life (explanatory variables) with the distribution of correct answers per question (response variable) was inferred through contingency tables tested through Chi-square tests implemented in the function chisq in R's base package.

Table 2 Majoring degrees association to each of the intended major field of study used as predictor classes in this study

\begin{tabular}{ll}
\hline Major field of study & Majoring degrees \\
\hline Agrarian Sciences & $\begin{array}{c}\text { Agroecology, Agronomy, Agrarian Sciences, Fishery Engineering, Forest Engineer- } \\
\text { ing, Veterinary Medicine, and Zootechnics }\end{array}$ \\
Biological Sciences & Biotechnology, Biological Sciences, and Oceanography \\
Exact Sciences & Biomedical Informatics, Civil Engineering, Computer Engineering, Computer \\
& Science, Food Engineering, Information Systems, Mathematics, Physics, and \\
& Surveying Engineering \\
Human Sciences & Accounting Sciences, Advertising and Marketing, Architecture and Urbanism, Arts \\
& and Design, Business Administration, Economy, Foreign Trade, Law, Letters, \\
& Music, Pedagogy, Philosophy, Psychology, and Visual Arts \\
Health Sciences & Biomedical Sciences, Medicine, Nursery, Pharmacy, Physiotherapy, and Physical \\
& Education \\
\hline
\end{tabular}


Generalized linear regression models (GLMs) were used to evaluate the relationship of major field of study and philosophy of life with the comprehension of ET. The number of correct answers per participant was the response variable, and the categories of major field of study and philosophy of life were explanatory variables. A quasi-Poisson distribution, fit for count data with overdispersion, was used in both models. A post hoc Tukey's test was performed, applying the function ghlt of package multcomp (v. 1.4-10) (Hothorn et al. 2008), to verify differences between categorical variables.

The distribution of correct answers, considering the interaction between major field of study and philosophy of life, was evaluated through contingency tables and tested through the function chisq in R's base package.

\section{Results}

\subsection{Descriptive Analyses}

After data screening and cleaning, the responses of 153 students were used to compare the performance of different areas on the number of correct answers per question. Questions seven and nine presented the lowest percentage of correct answers (32\% and 39\%, respectively). On the other hand, questions four and ten presented the highest percentage of correct answers (84\% and 87\%, respectively) (Table 3 and Fig. 1). Question seven asks what are the main sources of genetic variation, the basis of the evolutionary process, and question nine deals with homology. Questions number two, four, six, and seven are a block dealing with natural selection. In this block, interviewees showed much lower performance in question seven. Questions number five, seven, nine, and eleven deal with the genetic and phylogenetic basis of evolution. The performance in this block was superior on questions five and eleven, and much lower in questions seven and nine.

After data screening and cleaning, the responses of 130 students were used to compare the different philosophy of life performances on the number of correct answers for each question. Questions eight and ten, about human evolution and Lamarckism, respectively, presented the lowest percentage of correct answers (32\% and 39\%, respectively). Questions four and five, respectively about natural selection and genetic drift, presented the highest percentage of correct answers (84\% and 87\%, respectively) (Table 3 and Fig. 2).

\subsection{Major field of study is Correlated with Evolution Perception.}

The major field of study was related to freshman knowledge about biological evolution (df $=148, F=6.394, p<0.000$ ) (Fig. 3). On average, freshmen in the Biological Sciences showed similar performance to the freshmen enrolled in the Humanities, but they had better performance than the freshmen enrolled in each of the other major field of study (Fig. 3).

\subsection{Religion is Negatively Related to the Perception of Evolution.}

Knowledge of ET by freshmen in Brazilian universities was related to their religious and philosophical views. Self-declared atheists or agnostics answered, on average, more 


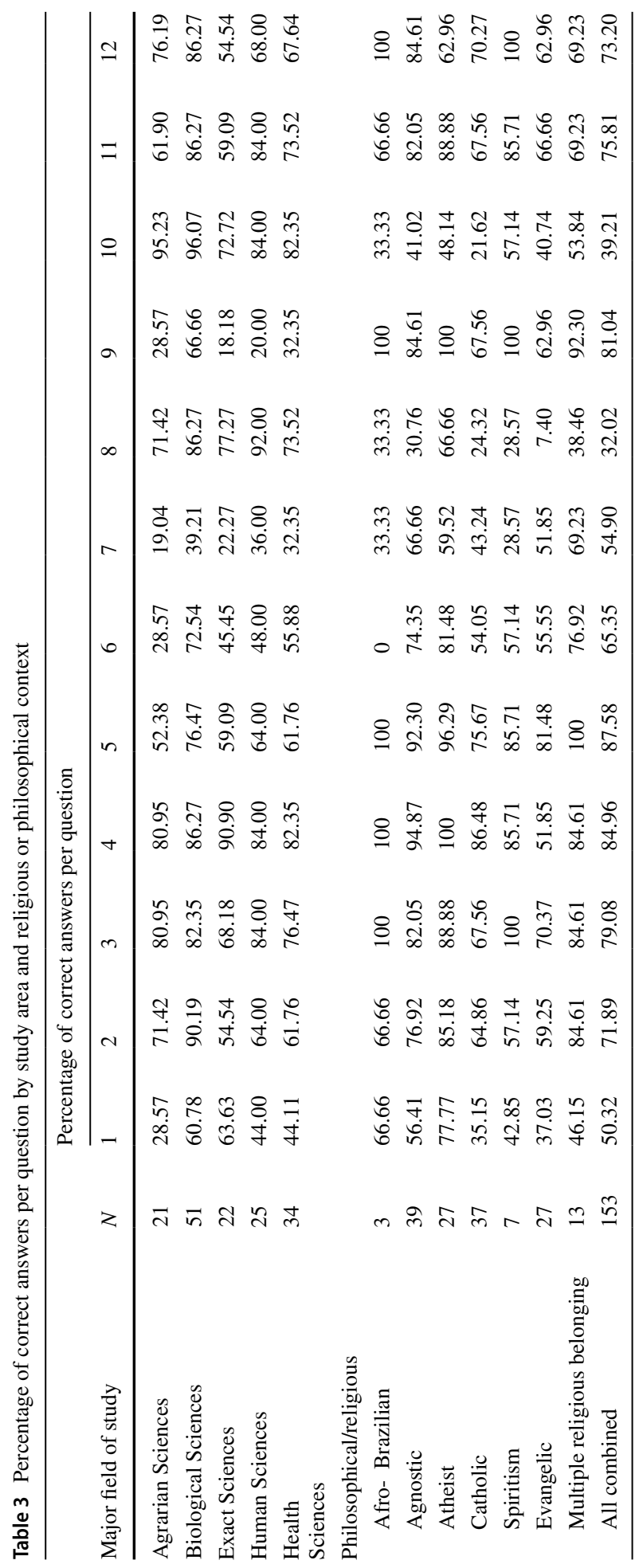




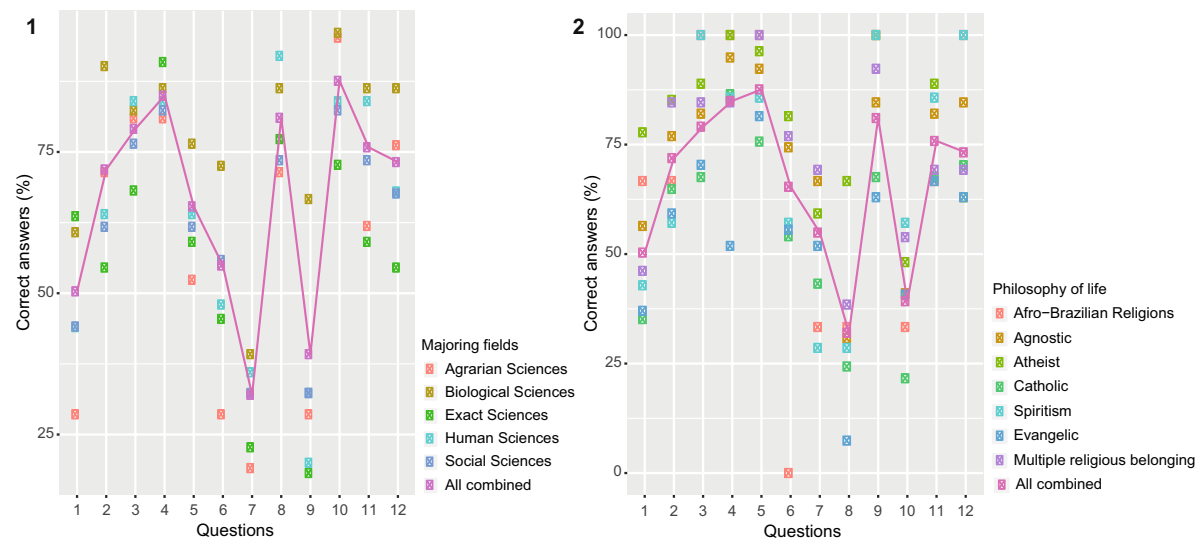

Fig. 1-2 Percentage of correct answers per question considering (1) the major field of study and (2) the philosophy of life of the students. The pink continuous line represents the average answer per question taking into account all data combined. In general, it is possible to note that the frequency of correct answers per question exhibits similar patterns for each category, showing that all categories tend to give more correct answers in the same questions when considering major field of study or philosophy of life

questions correctly than those declaring any religious belonging $(\mathrm{df}=126, F=10.024$, $p<0.000)$.

Pairwise comparisons (Fig. 4) between the four categories of the philosophy of life (atheist, agnostic, Catholic, Evangelical),showed that Catholics and Evangelicals responded similarly to each other. On the other hand, atheists and agnostics responded similarly to each other, but presented a better performance than Catholics and/or Evangelical students. Differences were found in every other comparison on the number of correct answers between areas, with better performance from atheists and agnostics.

\subsection{The Interaction of Disciplinary and Philosophy of Life on Evolution Perception.}

Both philosophies of life and major field of study influenced the number of correct answers by interviewees $\left(\mathrm{df}=12, \chi^{2}=171.07, p<0.000\right)$. However, each category of the philosophy of life showed a different performance on each major field of study (Fig. 3), lacking clear trends (Fig. 5).

\section{Discussion}

In our study, freshmen from different major field of study and philosophy of life showed similar qualitative performances at any question, which showed consistency in their knowledge shortcomings. Thus, the field of knowledge or the philosophy of life were not strong determinants to differentiate students' performance per question. Nonetheless, the grouping factor changed the results. Freshmen grouped by major field of study showed lower performance on questions seven and nine, whereas questions eight and ten showed the lowest number of right answers when considering students' philosophy of life. 

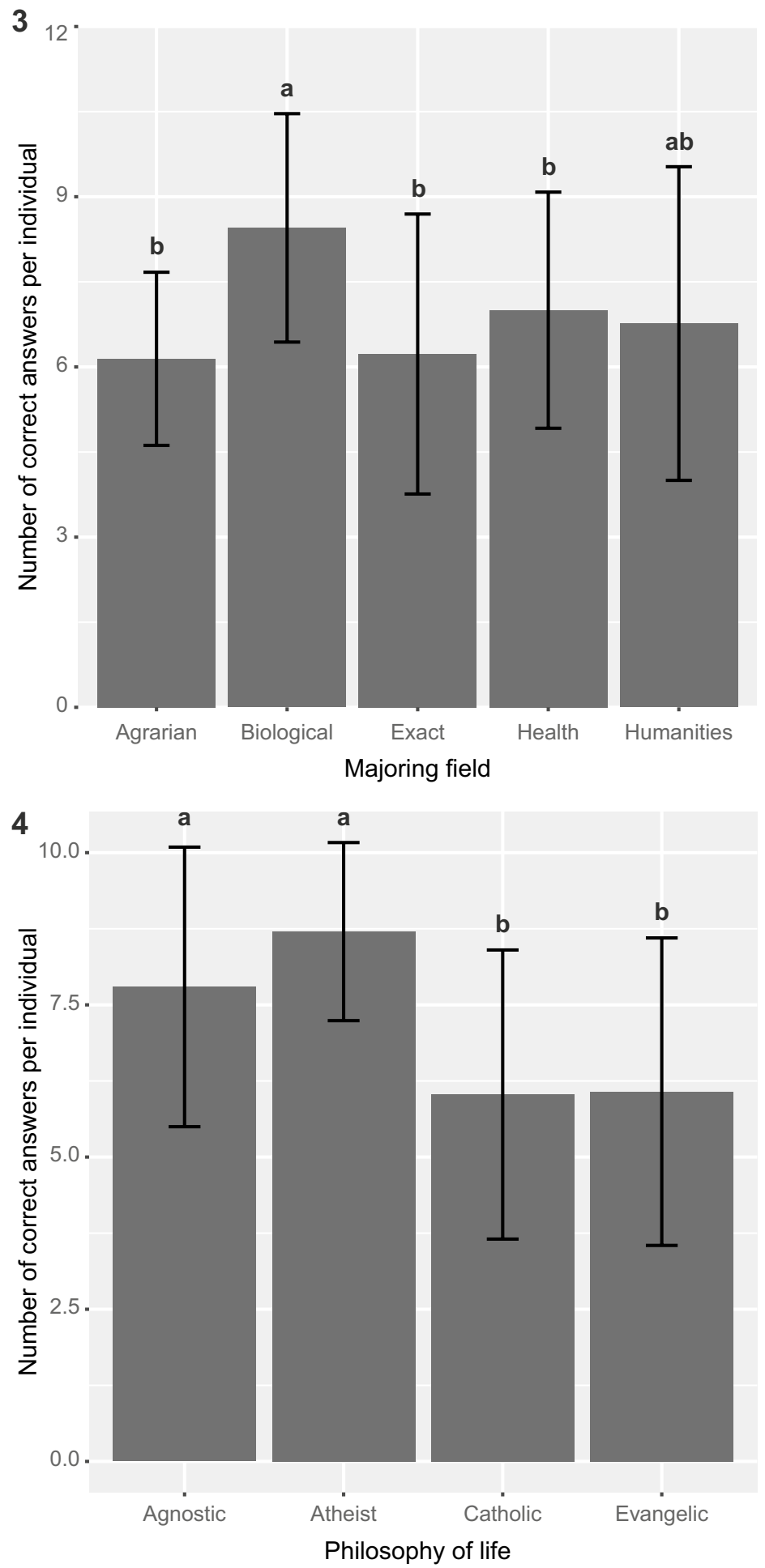
Fig. 3-4 Number of correct answers per individual (average \pm standard deviation), grouped by (3) major field of study $(N=153)$ and $(4)$ philosophy of life $(N=130)$. Bars followed by the same letter are not statistically different (Tukey's test, alpha $=0.05$ )

Two questions scored a higher frequency of correct answers. One of these questions, about the novelty of Darwin's idea regarding the modification in living organisms compared with the existing theories at that time, was also one of the questions answered more correctly in the study by Pazza et al. (2010). The other question with a high correct answer in our dataset was about the evolutionary process behind Lamarck's theory. These two central themes for ET, usually considered mutually exclusive, are the most present in textbooks used during basic education in Brazil (Bizzo, 1994; Tomotani \& Salvador, 2017; Zamberlan \& Silva, 2012). The idea of evolution of the fittest and Lamarck's giraffes are treated almost anecdotally in classrooms.

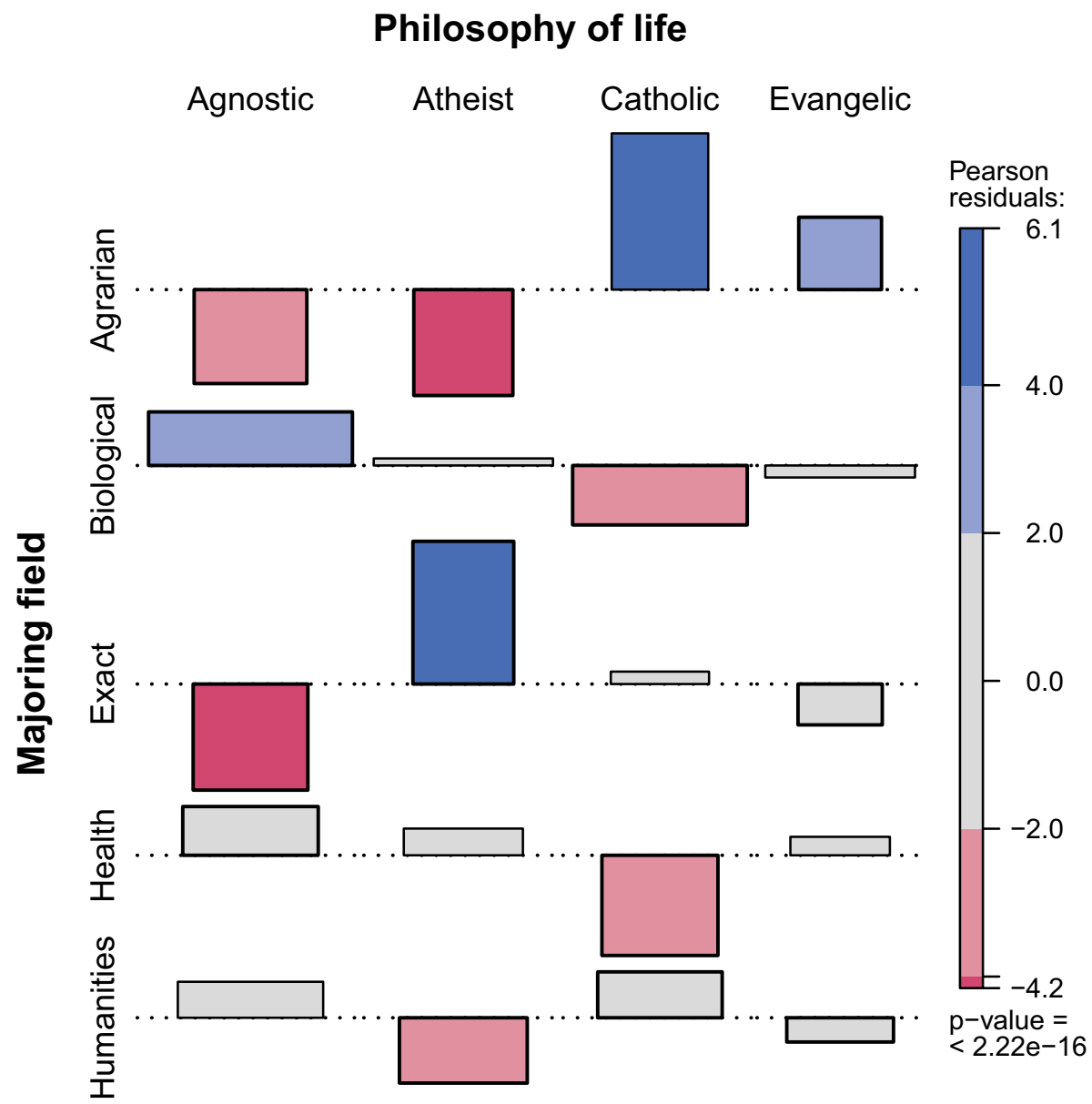

Fig. 5 Association plot of major field of study and philosophy of life. The color of the bars represents the magnitude of Pearson residuals, which are considered to differ from the expected values when they are higher than four. No clear pattern on the dependence of philosophy of life and the major field of study was found in the frequency of correct answers in each major field of study when considering the philosophy of life 
The second question with a high percentage of correct answers in Pazza et al. (2010) deals with the importance of mutation for evolution, which in our dataset showed on average $75 \%$ of correct answers. These data may reflect the ability of science high school teachers in teaching some topics of ET and also the importance that is granted to some topics in detriment of others during the students' experiences in high school. For example, Tidon and Lewontin (2004) showed that Brazilian teachers usually find it easier to explain the differences between Darwinian and Lamarckian approaches to evolution, and Caldeira et al. (2012) argued that Brazilian teachers do recognize the importance of natural selection for the construction of the evolutionary context. Teachers that attend more class hours of ET during their major courses usually dedicate more time for evolutionary teaching in their biology classes (Berkman et al., 2008), which may account for up to $60 \%$ more time in teaching evolution than others. Even though Brazilian freshmen recognize mutations are not harmful to evolution, they cannot recognize mutation and recombination as sources of evolutionary variation. Pazza et al. (2010) suggested that freshmen also fail to distinguish the origin of variation from natural selection itself.

The second most incorrectly answered question in our data set concerned the notion of homology. Different structures are homologous when they share a common ancestral origin, and homology is considered the main evidence of evolution. Kampourakis and Zogza (2008) suggested students' have an unconscious bias of anthropomorphically thinking and that it may drive them to attribute the similarities of organisms to a kind of kinship among them.

The amount of right and wrong answers is not distributed equally among questions and is influenced by the grouping classification, suggesting different degrees on the acceptance of creationism may generate different comprehension levels of ET (Penteado et al., 2012). Classification by major field of study and philosophy of life is based on different epistemological beliefs, which may be, in this case, directly linked to the acceptance or not of ET. For first-year life-science students, religion and major field of study are the most useful variables to predict scores when answering questions about evolution (Betti et al., 2020). It is noteworthy that the acceptance of ET, especially regarding human evolution, is much more related to an open-minded state than factual knowledge of evolution (Sinatra et al., 2003).

The major field of study was determinant for the overall knowledge about evolution by Brazilian freshmen students, measured as the total amount of correct answers. The students enrolled in undergraduate courses associated with the Biological Sciences showed higher performance than those from other fields of knowledge. Since evolution is a cornerstone for biology comprehension (Ashraf \& Sarfraz, 2016; Russo \& André, 2019), freshmen from Biological Sciences may be more prone to be interested in evolution, which would lead them to a higher knowledge on this subject or better memorization of its concepts. Students from Biological Sciences have shown better performance about evolution (Pazza et al., 2010) and are more prone to accept evolution independent of their religious beliefs (Hokayem \& BouJaoude, 2008). Also, students of the Biological Sciences and Humanities showed higher performance than students of other fields of knowledge, suggesting a different trend from the findings of Pazza et al. (2010). They found that students majoring in the Human and Exact Sciences showed similar performance but lower performance than students majoring in Biological Sciences. These comparisons should be cautiously evaluated because of the different approaches of both studies, since one interviewed high school students (Hokayem \& BouJaoude, 2008) while the other (Pazza et al., 2010) drew its conclusions from freshmen college students. 
Another interesting trend in our data was that all freshmen students tended to show lower performance in the same questions, even though, on average, the students from the Biological Sciences fared better. In general, students entering colleges have little knowledge about evolution (Moore et al., 2009, 2011). In this sense, students misconceptions about evolution are linked to several factors, ranging from the notion of a negative impact of ET on social processes such as racism (Brem et al. 2003) to students religious beliefs (Brem et al. 2003; Moore et al., 2009, 2011), their certainty on the subject (Ha et al., 2012), and the knowledge of the biology teachers in high school (Nehm and Schonfield 2017).

Religious beliefs play an important part in the acceptance of evolution (Clores \& Limjap, 2006) and may determine the role of teachers in the understanding of evolution by their students (Trani, 2004). Atheists or agnostic freshmen students performed, on average, better than Catholic and Evangelical freshmen students, showing the important role of philosophy of life to the understanding of ET. However, English students declaring different religious affiliations (other than Christian or Muslim) showed similar levels of acceptance of evolution as atheists or students for whom religion was not an important aspect of their life (Betti et al., 2020). Philosophical materialism (atheism) and theism are the two major worldviews that are relevant to teaching ET (Anderson, 2007). According to philosophical materialism, matter exists, there is no acknowledgment of God or gods, and ethics are human constructs; but to theism, God exists and created the universe and the living things, there is life after death, and ethics originates from God.

A person with a theistic worldview may not be necessarily religious, but all religious people subscribe to the theistic worldview. Epistemologically, religion and science can be considered as "non-overlapping magisteria" (Gould, 1997) but pedagogically these two magisteria can potentially overlap with each other in a student's mind. This potential overlap specifically fuels the opposition of the antievolution movement to teaching the theory of evolution. The driving force of the antievolution movement goes beyond the possibility of students to learn about the sciences (especially evolution), and it is mainly concerned about the implication of learning ET on students' worldviews and religious beliefs. The challenges for teaching and learning evolution are dependent on a series of factors related to the beliefs and training of the subjects. Religious students may even accept ET at different levels based on their perception about the religious philosophy behind ET. If highly religious students understand ET as atheistic, they are more prone to not accept its scientific conclusions when compared to those that perceive ET as agnostic (Barnes et al., 2020).

The understanding of the ET should be built from the students' life experiences, not to replace their previous knowledge on ET but intending to grant tools for a more conscious decision making by this student when analyzing problem situations in natural systems (Martínez 2003). This process should allow the student to evaluate when and how each magisteria, ET or religious beliefs, are to be accessed and applied, since there is evidence of an increase in the acceptance of Intelligent Design in Brazil (Silva, 2017) and that religious students may be prone to not separate their own religious beliefs from their evaluation of controversial topics in Science, as ET (Leão et al., 2020).

Confining ET within the philosophical materialist worldview provides additional fuel and fervor for anti-evolution movements that are motivated by their strong commitment to the preservation of their theistic worldview. Evolutionary theory provides an explanation for a great variety of biological phenomena that are more linked with other empirical evidence than the alternative explanations. Inner emotional processes should be accounted for when teaching evolution (Thagard \& Findlay, 2009) because people often shape their beliefs by their goals, a process that psychologists call motivated inference (Kunda, 1990). 
In our data, an interesting pattern arose. When comparing the number of correct answers per philosophy of life we did not find differences between atheistic students and agnostic students, and both groups presented a higher percentage of correct answers. This may point to the fact that the belief in God or a higher metaphysic force by itself does not prevent the students from understanding and applying basic knowledge on evolution. On the other hand, those who self-identified in a religious context (considering that due to the number of samples we could only statistically analyze answers of Christian students) presented a poorer performance to the number of correct answers. In this sense, we need to convey to our students that scientists are methodological materialists but not necessarily philosophical materialists. In other words, scientists do not use supernatural explanations while conducting and publishing scientific research, but they can interpret their scientific understanding and research findings from the perspective of their theistic worldview. Easterbrook (1997) reported that about $40 \%$ of working scientists have serious religious beliefs, based on survey items including explicit statements about believing in a personal God and praying.

We could not find a clear pattern of interaction between major field of study and philosophy of life. It is possible that for most of the students interviewed for this paper, as discussed above, religion and science can be considered as "non-overlapping magisteria" (Gould, 1997). In this way, we were not able to detect any specific performance pattern of each philosophy of life when accounting for the different major field of study. This may be related to the fact that when students have some knowledge of evolution, they can separate the answers that are expected in an "evolution knowledge text" and provide them despite their religious belief. However, it is important to recognize that knowledge is different from acceptance; knowledge can, in some cases, be used as a good predictor of acceptance of ET (Weisberg et al., 2018), but this relationship is complex and not straight (Nehm et al., 2007; Sinatra et al., 2003).

Brazil has experienced a rise of creationist movements (Oliveira and Kook, 2018), materialized in events like The Fifth International Congress of Creationists - UNASP and the First Seminar for Training Creationist Teachers in 2005 (Silva \& Prado, 2010), and the claims of respected teachers of Brazilian universities on evolution being "just a theory" (Silva, 2020). This movement is not limited to the scientific realm but also culminated in important executive decisions, such as the appointment of declared creationists to the management of public agencies, such as CAPES - the Brazilian Higher Education Improvement Coordination (Escobar, 2020) and the Ministry of Education.

Although we are aware that the sum of correct answers in a text may not completely reflect one's relationship with the acceptance of ET, some of the drivers raised by us in this paper, such as major field of study and philosophy of life, are determinants for a student's knowledge on the basics of ET. This is of special concern since the broad public acceptance of the benefits of science and technology in the second half of the twentieth century allowed science to develop its activities to a level beyond partisan identification, which seems to be weaker every day (Miller et al., 2006). Besides, the understanding of ET is paramount since its comprehension will allow these students to more effectively deal with pressing subjects, such as the use of antibiotics, pandemic diseases (e.g. AIDS and COVID-19) (Brüne \& Wilson, 2020; Varlese, 2008), and other hot-topic issues of our society, such as genetically modified organisms (Blancke et al., 2015) and indiscriminate use of pesticides (Hawkins et al. 2019).

Although Brazilian society has changed, little has changed about the understanding of ET by Brazilian freshmen during the last decade, even taking into account the differences in scale between Pazza et al. (2010) and our study. Our data show that the knowledge on 
evolution by Brazilian freshmen may be seriously threatened by this rising ideological activism since the philosophy of life is the main driver of ET perception for this group (Betti et al., 2020). In this sense, scientists and teachers must be aware of their part in reassuring the role of science and scientific knowledge in modern societies. This is especially important when dealing with subjects that are still rejected or miscomprehended by the majority of the population, such as ET, since the acceptance of evolution is much like a Hydra, with many diverse and hard to kill heads (Allmon, 2011).

We reinforce the importance of Life Science workers and scientists joining forces with education professionals to ensure the effective teaching of evolution in Brazilian schools and universities. In this sense, we propose that further investigations should focus on how non-Christian religions are effectively related to the ET knowledge and how the morality concept in different religions may relate to ET knowledge and the use of scientific knowledge in the decision-making based on morality.

Supplementary Information The online version contains supplementary material available at https://doi. org/10.1007/s11191-021-00286-z.

Acknowledgements We acknowledge the 849 Brazilian students that answered our questionnaire, especially the 153 freshmen students. We are also grateful to Michael Forthman for editing the manuscript for proper English and for comments that improved the manuscript. We also thank the two anonymous reviewers, whose thorough comments helped to improve the quality of the manuscript.

Funding No funding was received to assist with the preparation of this manuscript.

\section{Declarations}

Conflicts of interest/Competing interests All authors certify that they have no affiliations with or involvement in any organization or entity with any financial interest or non-financial interest in the subject matter or materials discussed in this manuscript.

\section{References}

Abrantes, P., \& Almeida, F. P. L. (2006). Criacionismo e Darwinismo confrontam-se nos tribunais da razão e do direito. Episteme: Filosofia e História das ciências em revista, 11(24), 357-401.

Allmon, W. D. (2011). Why don't people think Evolution is true? Implications for teaching, in and out of the Classroom. Evolution: Education and Outreach, 4, 648-665.

Alves, J. E., Cavenaghi, S., Barros, L. F., \& Carvalho, A. A. (2017). Distribuição espacial da transição religiosa no Brasil. Tempo Social, 29(2), 215-242.

Amorim, M. C., \& Leyser, V. (2009). Ensino de evolução biológica: implicações éticas da abordagem de conflitos de natureza religiosa em sala de aula. In: Atas do VII Encontro Nacional de Pesquisas em Educação em Ciências (ENPEC). Florianópolis: ABRAPEC.

Anderson, R. D. (2007). Teaching the theory of evolution in social, intellectual, and pedagogical context. Science Education, 91, 664-677.

Ashraf, M. A., \& Sarfraz, M. (2016). Biology and evolution of life science. Saudi Journal of Biological Sciences, 23, S1-S5.

Baker, J. O. (2013). Acceptance of evolution and support for teaching creationism in public schools: The conditional impact of educational attainment. Journal for the Scientific Study of Religion, 52(1), 216-228.

Baker, S. (2010). Creationism in the classroom: A controversy with serious consequences. Research in Education, 83(1), 78-88.

Barnes, M. E., Dunlop, H. E., Sinatra, G. M., Hendrix, T. M., Zheng, Y., \& Brownell, S. E. (2020). Accepting Evolution Means You Can't Believe in God: Atheistic perceptions of evolution among college biology students. CBE-Life Sciences Education, 19(ar21), 1-13. 
Berkman, M., Pacheco, J., \& Plutzer, E. (2008). Evolution and creationism in America's classrooms: A national portrait. PLoS Biology, 6(5), e124.

Berkman, M., \& Plutzer, E. (2010). Evolution, Creationism, and the Battle to Control America's Classrooms. Cambridge University Press.

Betti, L., Shaw, P., \& Behrends, V. (2020). Acceptance of biological evolution by first-year life sciences university students. Science \& Education, 29, 395-409.

Blancke, S., Peter, C., \& Kjærgaard, P. C. (2016). Creationism invades Europe. Scientific American. Retrieved, November 11, 2020, from https://www.scientificamerican.com/article/eurocreationism/

Blancke, S., Van Breusegem, F., De Jaeger, G., Braeckman, J., \& Van Montagu, M. (2015). Fatal attraction: The intuitive appeal of GMO opposition. Trends in Plant Science, 20(7), 414-418.

Bizzo, N. V. M. (1994). From down house landlord to Brazilian high school students: What has happened to evolutionary knowledge on the way? Journal of Research in Science Teaching, 31(5), 537-556.

Brasil. (1988). Constituição da República Federativa do Brasil. Brasília, DF: Senado Federal: Centro Gráfico. Retrieved November 11, 2020, from http://www.planalto.gov.br/ccivil_03/constituicao/constituic ao.htm

Brasil. (2006). Orientações Curriculares para o Ensino Médio. Retrieved November, 12 2020, from https:// portal.mec.gov.BR/se/arquivos/p.f./book_volume_02_internet.pdf.

Brasil. (2017). Base Nacional Comum Curricular (BNCC). Educação é a Base. Brasília, MEC/CONSED/ UNDIME. Retrieved November 12, 2020, from http://basenacionalcomum.mec.gov.br/images/BNCC_ EI_EF_110518_versaofinal_site.pdf

Brasil. (2018) Censo da Educação Superior 2018: Sinopse estatística. Brasília, MEC/INEP. Retrieved September 7, 2021 from https://download.inep.gov.br/informacoes_estatisticas/sinopses_estatisticas/sinop ses_educacao_superior/sinopse_educacao_superior_2018.zip

Brenan, M. (2019). 40\% of Americans believe in creationism. Gallup News. Retrieved June 25, 2021, from https://news.gallup.com/poll/261680/americans-believe-creationism.aspx

Brewer, C. A., \& Smith, D. (2011). Vision and change in undergraduate biology education: A call to action. American Association for the Advancement of Science.

Brum, E., Fonseca, C., \& Cardoso, N. (2005). E no princípio era o que mesmo? Época. Retrieved November 11, 2020, from http://revistaepoca.globo.com/Revista/Epoca/0,EDG68197-6014,00-E+NO+PRINC IPIO+ERA+O+QUE+MESMO.html

Brüne, M., \& Wilson, D. R. (2020). Evolutionary perspectives on human behavior during the coronavirus pandemic: Insights from game theory. Evolution, Medicine, and Public Health, 2020(1), 181-186. https://doi.org/10.1093/emph/eoaa034

Caldeira, A. M. A., Araújo, E. S. N. N., \& Carvalho, G. S. (2012). Creationism and evolution views of Brazilian teachers-to-be. Journal of Life Sciences, 167, 279-287.

Clores, M. A., \& Limjap, A. A. (2006). Diversity of students' beliefs about biological evolution. Asia Pacific Journal of Education, 26(1), 65-77. https://doi.org/10.1080/02188790600607960

Datafolha. (2010). Pesquisa de opinião pública sobre o criacionismo. Folha de São Paulo, 29.584. Retrieved June 25, 2021, from https://datafolha.folha.uol.com.br/opiniaopublica/2010/04/1223573-59-acreditamna-evolucao-entre-as-especies-sob-o-comando-de-deus.shtml

Easterbrook, G. (1997). Science and God: A warming trend. Science, 277, 892.

Egger, P. W., Delouvée, S., Gauvrit, N., \& Dieguez, S. (2018). Creationism and conspiracism share a common teleological bias. Current Biology., 28, R847-R870.

Escobar, H. (2019). Bolsonaro's first moves have Brazilian scientists worried. Science, 363, 330.

Escobar, H. (2020). Brazil's pick of a creationist to lead its higher education agency rattles scientists. Science. https://doi.org/10.1126/science.abb0530

Gould, S. J. (1997). Nonoverlapping Magisteria. Natural History, 106, 16-22.

Follmann, J. I. (2017). Brazil, Catholic religion and education: Challenges and prospects. International Studies in Catholic Education, 9, 76-88. https://doi.org/10.1080/19422539.2017.1286912

Ha, M., Haury, D. L., \& Nehm, R. H. (2012). Feeling of certainty: Uncovering a missing link between knowledge and acceptance of evolution. Journal of Research in Science Teaching, 49(1), 95-121.

Harmon, K. (2011). Evolution abroad: Creationism evolves in science classrooms around the Globe. Scientific American. Retrieved November 11, 2020, from https://www.scientificamerican.com/article/evolu tion-education-abroad/

Hawkins, N. J., Bass, C., Dixon, A., \& Neve, P. (2019). The evolutionary origins of pesticide resistance. Biological Reviews, 94, 135-155. https://doi.org/10.1111/brv.12440

Hokayem, H., \& Boujaoude, S. (2008). College students' perceptions of the theory of evolution. Journal of Research in Science Teaching, 45(4), 395-419.

Interacademy Panel (2006). Interacademy Panel statement on the teaching of evolution. Retrieved November 11, 2020, from https://www.interacademies.org/sites/default/files/2020-05/Evolution\%20statement.pdf 
Johnson, W. R., \& Lark, A. (2018). Evolution in action in the classroom: Engaging students in science practices to investigate and explain evolution by natural selection. The American Biology Teacher, 80(2), 92-99.

Kampourakis, K., \& Zogza, V. (2008). Students' intuitive explanations of the causes of homologies and adaptations. Science \& Education, 17, 27-47.

Kelemen, D. (2012). Teleological minds: How natural intuitions about agency and purpose influence learning about evolution. In K. S. Rosengren, S. K. Brem, E. M. Evans, \& G. M. Sinatra (Eds.), Evolution Challenges: Integrating Research and Practice in Teaching and Learning about Evolution (pp. 66-92). Oxford University Press.

Kunda, Z. (1990). The case for motivated inference. Psychological Bulletin, 108, 480-498.

Leão, I. M. S., Costa, F. J., Carvalho, G. S., \& Silva, H. M. (2020). Biological evolution and creationism from the perspective of graduate students of biological sciences. Góndola, Enseñanza y Aprendizaje De Las Ciencias, 15(2), 303-321.

Martinez, N. M. (2003). Conocimientos que interaccionan en la enseñanza de las ciencias. Enseñanza De Las Ciencias, 21(1), 65-78.

Meyer, D., \& El-Hani, C. N. (2005). Evolução e o sentido da biologia. São Paulo: Editora UNESP.

Miller, J. D., Scott, E. C., \& Okamoto, S. (2006). Public acceptance of evolution. Science, 313(5788), $765-766$.

Moore, R., Brooks, D. C., \& Cotner, S. (2011). The relation of high school biology courses \& students' religious beliefs to college students' knowledge of evolution. The American Biology Teacher, 73(4), 222-226.

Moore, R., Cotner, S., \& Bates, A. (2009). The influence of religion and high school biology courses on students' knowledge of evolution when they enter college. The Journal of Effective Teaching, 9(2), 4-12.

Navarro, A. (2018). Programa para educação de Bolsonaro enxerga Charles Darwin e Evolução como “doutrinação". Retrieved November 11, 2020, from http://www.esquerdadiario.com.br/Programa-paraeducacao-de-Bolsonaro enxerga-Charles-Darwin-e-Evolucao-como-doutrinacao

Nehm, R. H., \& ·Schonfeld, I. S. . (2007). Does increasing biology teacher knowledge of evolution and the nature of science lead to greater preference for the teaching of evolution in schools? Journal of Science Teacher Education, 18, 699-723. https://doi.org/10.1007/s10972-007-9062-7

Oleques, C. L., Bertholomei-Santos, L. M., \& Boer, N. (2011). Evolução Biológica: Percepções de professores de biologia. Revista Eletrónica De Enseñanza De Las Ciências, 10(2), 243-263.

Oliveira, A. W., \& Cook, K. L. (2018). Evolution Education and the rise of the creationist movement in Brazil. In H. Deniz \& L. A. Borgerding (Eds.), Evolution Education around the Globe (pp. 119-135). Springer.

Pazza, R., Penteado, P. R., \& Kavalco, K. F. (2010). Misconceptions about evolution in Brazilian freshmen students. Evolution: Education and Outreach, 3(107), 113.

Penteado, P., Kavalco, K., \& Pazza, R. (2012). Influence of sociocultural factors and acceptance of creationism in the comprehension of evolutionary biology in freshman Brazilian students. Evolution: Education and Outreach, 5, 589-594.

R Core Team. (2019). R: A language and environment for statistical computing. R Foundation for Statistical Computing, Vienna, Austria. Retrieved November 11, 2020, from https://www.R-project.org/

Russo, C. A. M., \& André, T. (2019). Science and evolution. Genetics and Molecular Biology, 42(1), $120-124$.

Sepulveda, C. A. S., \& El-Hani, C. N. (2004). Quando visões de mundo se encontram: Religião e ciência na trajetória de formação de alunos protestantes de uma licenciatura em ciências biológicas. Investigações Em Ensino De Ciências, 9(2), 137-175.

Silva, H. M. (2017). Intelligent design endangers education. Science, 357(6354), 880-880.

Silva, H. M. (2020). Ark of absurdities creationism comes to Brazil. Skeptic, 25(2), 26-30.

Silva, H., \& Prado, I. G. O. (2010). Creationism and intelligent design: Presence in the Brazilian educational policy. Procedia Social and Behavioral Sciences, 2, 5260-5264.

Sinatra, G. M., Southerland, S. A., McConaughy, F., \& Demastes, J. W. (2003). Intentions and beliefs in students' understanding and acceptance of biological evolution. Journal of Research in Science Teaching, 40(5), 510-528.

Thagard, P., \& Findlay, S. (2009). Getting to Darwin: Obstacles to accepting evolution by natural selection. Science \& Education, 19, 625-636.

Tidon, R., \& Lewontin, R. C. (2004). Teaching evolutionary biology. Genetics and Molecular Biology, 27(1), 124-131.

Tomotani, J. V., \& Salvador, R. P. (2017). Análise do conteúdo de Evolução em livros didáticos do Ensino Fundamental brasileiro. Pesquisa e Ensino Em Ciências Exatas e Da Natureza, 1(1), 05-18.

Trani, R. (2004). I won't teach evolution; it's against my religion. And now for the rest of the story. The American Biology Teacher, 66, 419-427. 
Varlese, E. N. (2008). To Believe or not to believe? A college student explores knowledge and attitudes about evolution at her school. Evolution: Education and Outreach, 1, 96-99.

Weisberg, D. S., Landrum, A. R., Mets, E., \& Weisberg, M. (2018). No missing link: Knowledge predicts acceptance of evolution in the United States. BioScience, 68, 212-222.

Zamberlan, E. S. J., \& da Silva, M. R. (2012). O Ensino de Evolução Biológica e sua Abordagem em Livros Didáticos. Educação Realidade, 37(1), 187-212.

Publisher's Note Springer Nature remains neutral with regard to jurisdictional claims in published maps and institutional affiliations. 